\title{
HORIZONTAL MOVEMENT OF FAST ICE IN THE NORTH WATER AREA
}

\author{
By Hajime Ito and Fritz MülleR \\ (Geographisches Institut, Eidgenössische Technische Hochschule Zürich, CH-8og2 Zürich, \\ Switzerland and McGill University, Montreal, Quebec, Canada)
}

\begin{abstract}
The understanding of the horizontal movement of fast ice is important for applied sea-ice mechanics. A case study, carried out in conjunction with a polynya known as North Water, is presented in this paper. The displacements of the fast-ice arches which separate the polynya from the surrounding ice-covered sea, were measured and found to be small. It is, therefore, confirmed that these arches prevent the influx of large quantities of sea ice into the polynya. The results are then explained in terms of the external forces (wind and current), the stress-strain situations and some physical characteristics (temperature and thickness) which were measured simultaneously.

RÉsumÉ. Mouvement horizontal de la glace fixée dans la zone de North Water. La compréhension du mouvement horizontal de la glace fixée est importante pour la mécanique appliquée de la glace de mer. Une étude de cas, menée dans un polynya connu sous le nom de North Water, est présentée dans ce papier. Les déplacements des arches de glace fixée, qui séparent le polynya de la banquise environnante, furent mesurés et trouvés faibles. Il est donc confirmé que ces arches empêchent l'afflux de grandes quantités de glace de mer dans le polynya. On explique alors les résultats en fonction des forces extérieures (vent et courant), des situations des contraintes et de quelques caractéristiques physiques (température et épaisseur) que l'on a mesuré simultanément.

Zusammenfassung. Die Horizontalbewegung des Festeises im North Water. Das Verständnis der Horizontalbewegung von Festeis ist für die angewandte Meereis-Mechanik von grosser Bedeutung. Die vorliegende Arbeit ist eine Fallstudie durchgeführt im North Water. Die Verschiebungen der Festeis-Bögen, die die Polynya vom umliegenden eisbedeckten Meer trennen, wurden gemessen und stellten sich als gering heraus. Dies bestätigt, dass diese Bögen den Zustrom grosser Mengen von Eis in die Polynya verhindern. Die Ergebnisse werden erklärt im Zusammenhang mit den äusseren Einwirkungen (Wind und Strömung), den Beziehungen zwischen den Spannungen und der Eisverformung, sowie einigen physikalischen Eigenschaften (Temperatur und Dicke), die gleichzeitig gemessen wurden.
\end{abstract}

\section{INTRODUCTION}

The North Water is a polynya located between Ellesmere Island and Greenland, bounded by fast-ice "arches" at its northern and western extremities, i.e. at Kane Basin, Jones Sound and Lancaster Sound (Fig. I). In assessing the cause of the polynya, the displacements of the arches have a two-fold significance:

I. A polynya can be interpreted as an area of small ice input and/or large ice output. One of the major modes of input and output is the transport of sea ice through the boundaries. Through the fast-ice boundary little sea ice appears to move into the polynya whilst large quantities of pack ice may be exported through the loose southern boundary. The position of the arches is indeed known to change very little with the seasonal advance. However, this fact does not necessarily mean that the influx through the fast ice boundary is nil. This was confirmed only by the measurement of markers fixed on the arches.

2. The mechanism of arch formation and maintenance, which is interesting enough in itself, becomes rather an important factor in the cause of the polynya if the ice influx through the arch is really nil. The movement of ice in the area of the arch is as important in the study of this mechanism as the external force and stress-strain situation. Fast-ice mechanics on the meso-scale, which has received little attention so far, becomes important as engineering activities in the Arctic increase (Ito and Müller, in press). This paper, though a case study, attempts to elucidate some basic meso-scale characteristics of fast ice. 


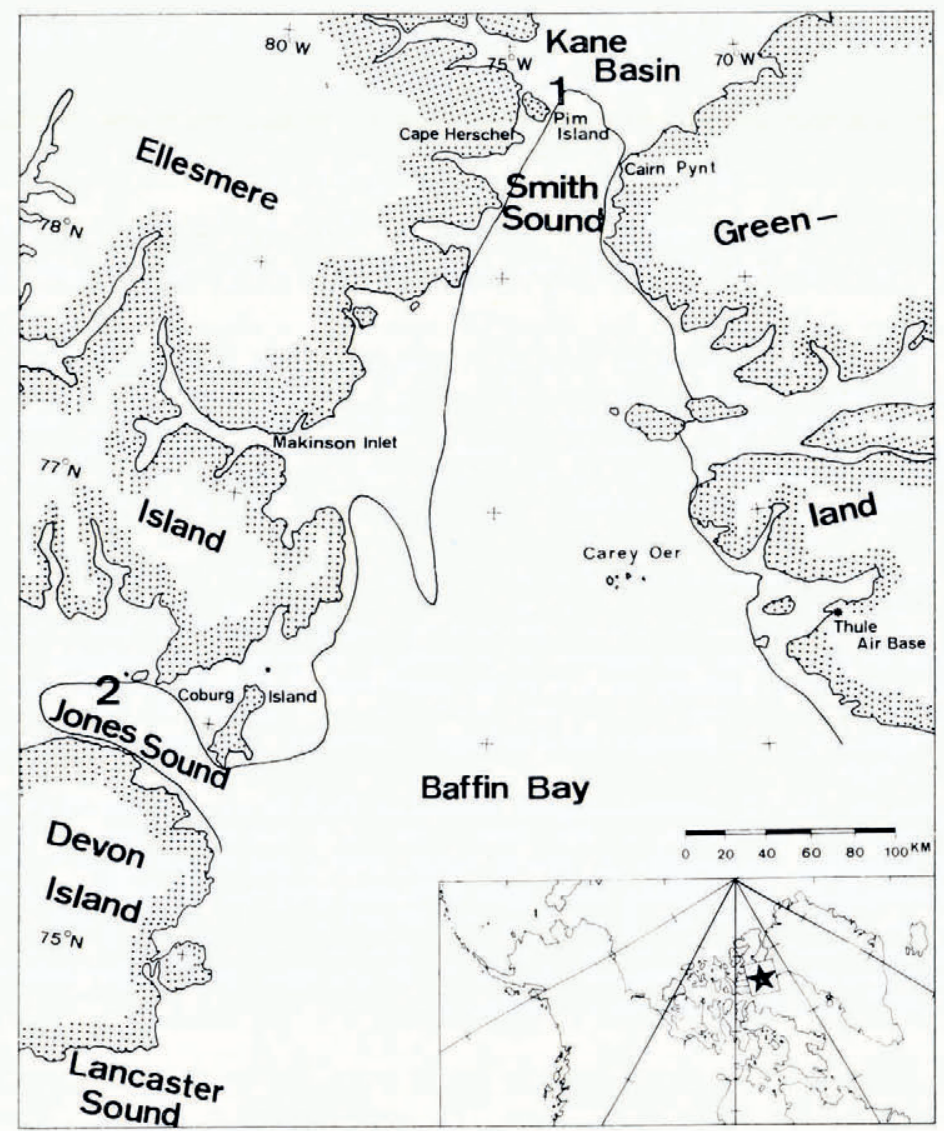

Fig. 1. North Water area with fast-ice boundary as per April 1974 (Müller and others, 1975):

1. Working area in 1974 and 1975 (enlarged in Fig. $2 A$ and B).

2. Working area in 1976 (enlarged in Fig. $2 C$ ).

Measurements from satellite or aircraft are not adequate for this purpose as the displacement of the fast ice is small. Classical surveying on the surface is the only method giving sufficient accuracy. However, this is difficult to carry out unless a helicopter and much manpower are available; lacking both, only a few measurements could be made so far.

\section{FiELD WORK}

Since 1972 the North Water Project of McGill University (Montreal) and of the Eidg. Technische Hochschule (Zürich) has carried out extensive glaciological and climatological field investigations of North Water (Müller and others, 1973). The displacement of the fast ice was measured in 1974, 1975 and 1976 together with other factors such as external forces (wind and current), stress-strain, and physical characteristics (temperature, salinity and thickness).

In 1974 markers were set on the fast ice in Kane Basin and their positions measured repeatedly from I April to 4 June at intervals of approximately $25 \mathrm{~d}$. In the beginning, while travelling on the sea ice was possible, the positions were fixed by traverse surveying using a Wild $\mathrm{T}_{2}$ theodolite and a Wild Distomat $\mathrm{DI}_{50}$ electronic distance measurer. The tranverse 
line, starting from a land station, extended $20 \mathrm{~km}$ along the fast-ice boundary. Poles with a diameter of $25 \mathrm{~mm}$ and a height of $2 \mathrm{~m}$ with $30 \mathrm{~cm} \times 40 \mathrm{~cm}$ flags were used as beacons. Later, when light conditions improved and travelling on the sea ice became impossible, intersections were made from three land stations, whose relative positions were surveyed separately. The poles were marked by $4 \mathrm{~m}$ high beacons for visibility over longer distances. The respective estimated errors for the angle and distance measurements was $10 \mathrm{~cm}$ and $5 \mathrm{~cm}$ for $2 \mathrm{~km}$, and $50 \mathrm{~cm}$ and $13 \mathrm{~cm}$ for $10 \mathrm{~km}$. The final error in the position depends on the distance of the point from the land stations. The largest error was estimated to be $70 \mathrm{~cm}$.

In 1975 similar but somewhat reduced field work was carried out in Kane Basin. Resection had to be employed instead of traversing due to adverse travelling conditions on the sea ice. Distances were not measured, but those between the land stations were known from the previous summer's survey. All five points were marked with $4 \mathrm{~m}$ high beacons. The measurement period was shorter than in 1974, lasting only from I May to I 7 June. The intervals between the five sets of measurements were irregular, varying from 5 to $25 \mathrm{~d}$. The estimated final error was as large as $\mathrm{I} \mathrm{m}$, due to the short temporary base line used for the resection; individual angle measurements, however, had smaller errors than in the previous summer.
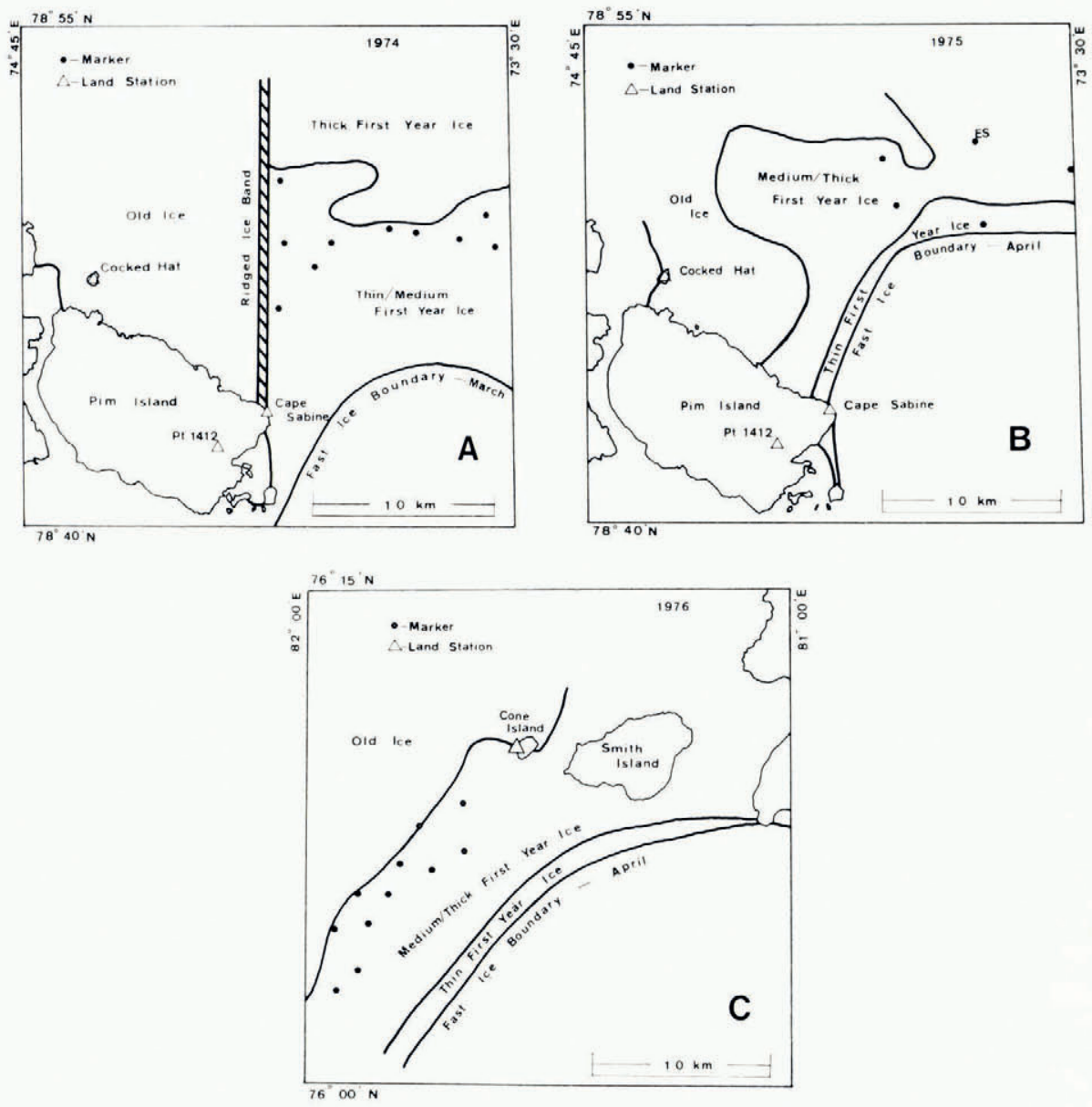

Fig. 2. Position of the markers in relation to the sea-ice situation in the Kane Basin/Smith Sound area in spring 1974 and in spring $1975(A$ and $B)$ and in Jones Sound in $1976(C)$. 
In 1976 Jones Sound was chosen for the field work. The positions of eleven markers set on the ice along the fast-ice boundary were related to a land station by triangulation. Distances were measured by steel tape and angles by theodolite. Three sets of measurements were made during the period $\mathrm{I}_{3}$ May to 2 June at intervals of approximately io d. The final errors of position were estimated to be up to $50 \mathrm{~cm}$.

Figure 2 shows the position of the markers in relation to the ice conditions of the surrounding area at the time of the first measurement.

The field work was usually carried out by two people travelling by skidoo.

\section{Results AND Discussion}

The displacement of the markers is shown in Figure 3. The amount of displacement is similar for the three years and generally small, i.e. of the order of tens of centimetres per day. A numerical model of the Kane Basin-Smith Sound ice system using the finite-element method assuming a Newtonian law (as yet unpublished) showed a similar magnitude. The rate of displacement was found to increase with the seasonal advance (April to June), as had

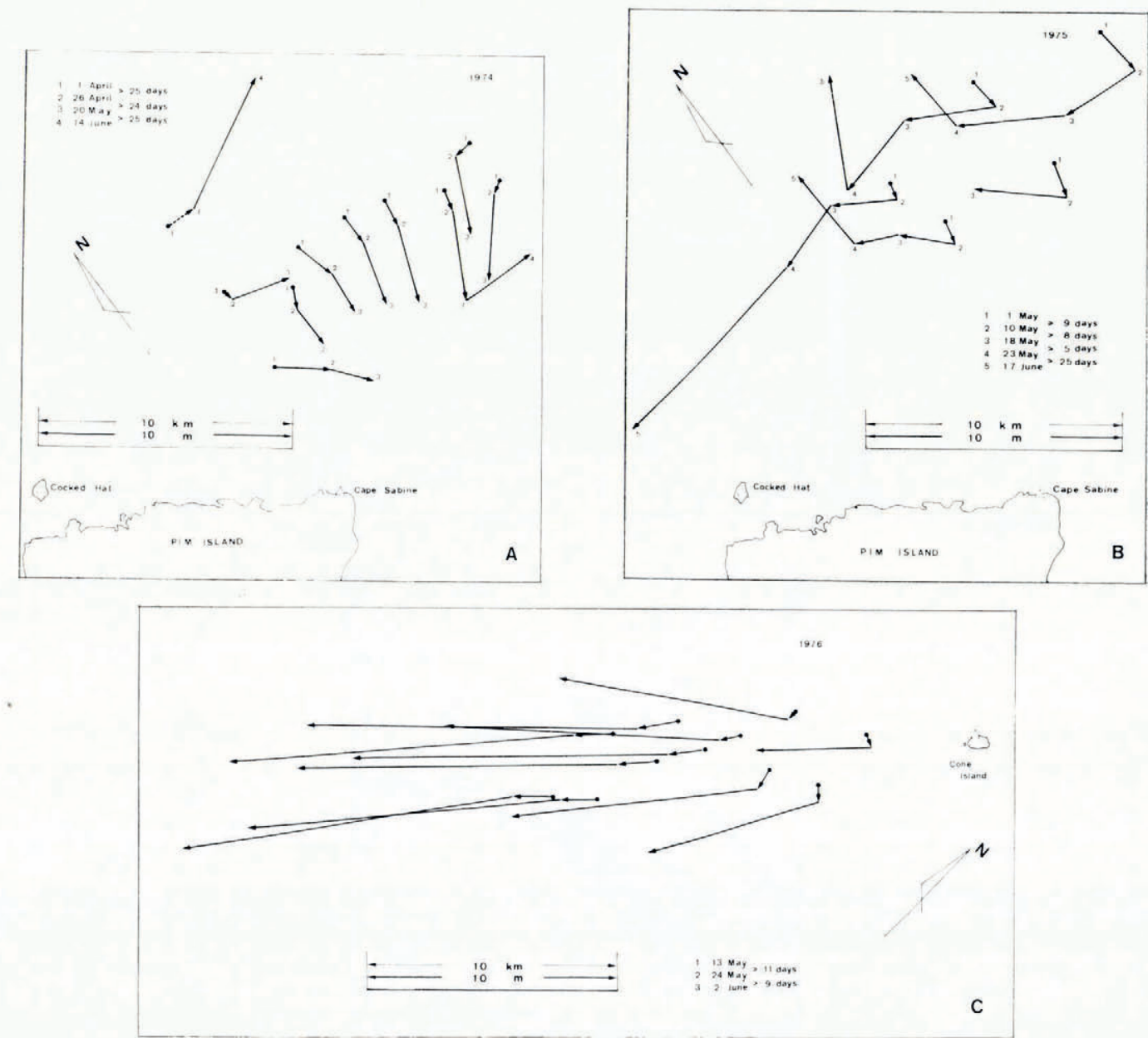

Fig. 3. Displacement of fast ice in the Kane Basin/Smith Sound area in 1974 and 1975 ( $A$ and $B$ ) and in Fones Sound in $1976(C)$. 
already been observed on the fast ice in Pond Inlet by Zick and Thiele (r972). To explain this phenomenon, air temperature and ice thickness for the 1975 measurement period are shown (Fig. 4). Ideally, ice temperatures should have been included, however air temperature is closely related to the ice temperature. Increasing temperature makes the ice softer while, at the same time, increasing thickness tends to strengthen, i.e. to harden, the sea-ice cover. The former effect predominated.

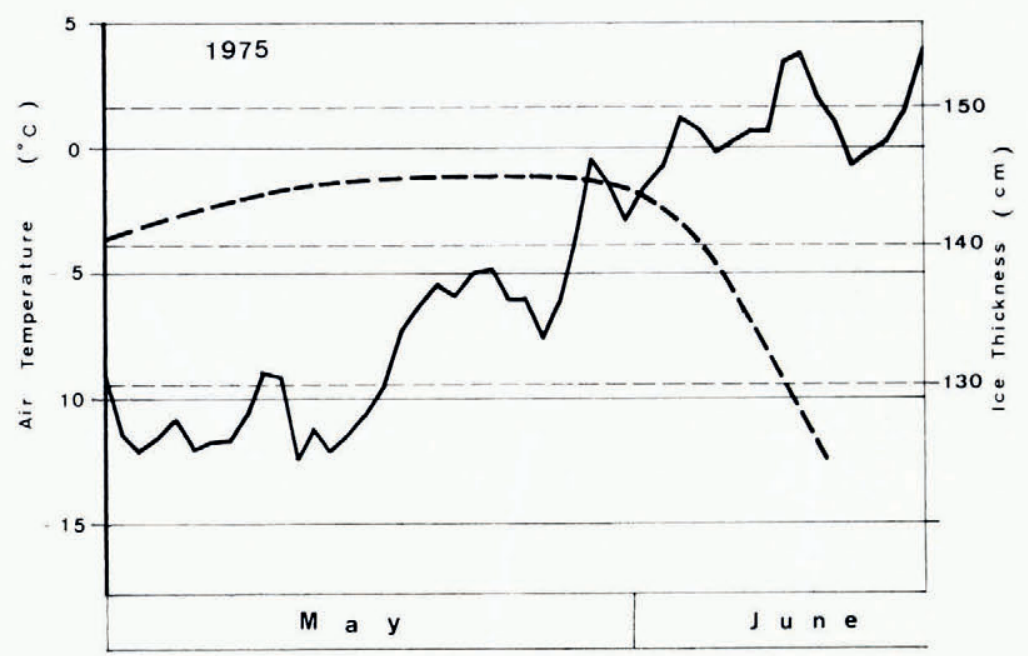

Fig. 4. Seasonal change of air temperature at Cape Herschel (solid line) and ice thickness at point ES in Kane Basin in 1975 (dashed line). The position of ES is shown in Fig. $2 B$.

The influx of ice through the northern arch into the polynya is calculated to be of the order of $10^{1} \mathrm{~cm} \mathrm{~d}^{-1} \times 10^{7} \mathrm{~cm}$ (length of the arch), i.e. $10^{8} \mathrm{~cm}^{2} \mathrm{~d}^{-1}$. This area can be regarded as negligible compared with that of the whole polynya which is estimated at $10^{15} \mathrm{~cm}^{2}$. Furthermore, observations show that a fast-ice strip of 2 to $3 \mathrm{~km}$ width is broken off in Kane Basin during storms with southerly winds and by easterly winds in Jones Sound. Assuming IO $^{-1}$ storm $\mathrm{d}^{-1}$, the influx from this source is estimated to be $10^{11} \mathrm{~cm}^{2} \mathrm{~d}^{-1}$, i.e. this form of ice input is also negligibly small.

The ice movement is initially directed into the polynya and is later reversed. This sudden change in direction can be explained by either one or both of two reasons. The situation is described for Kane Basin; for Jones Sound the directions north and south are to be read as west and east respectively.

(a) The major forces which cause the displacement of the fast ice are exerted by sea current and wind. The current runs steadily into the polynya with a speed of the order of $\mathrm{IO}^{1} \mathrm{~cm} \mathrm{~s}^{-1}$ estimating from field measurements made in Jones Sound on a time scale chosen large enough to average out the tidal effects. The dominant wind blows into the polynya, except during storms with southerly winds. Southward current and northerly wind together drive the ice into the polynya. Driving forces directed towards the north only occur when strong southerly winds prevail. Figure 5 shows the wind run measured at Cape Herschel as well as the resultant wind for the three displacement periods in 1974. In the earlier part of the observation period, northerly winds were predominant, hence the movement was southward. However, southerly winds dominated in the later period, hence northward movement occurred. 


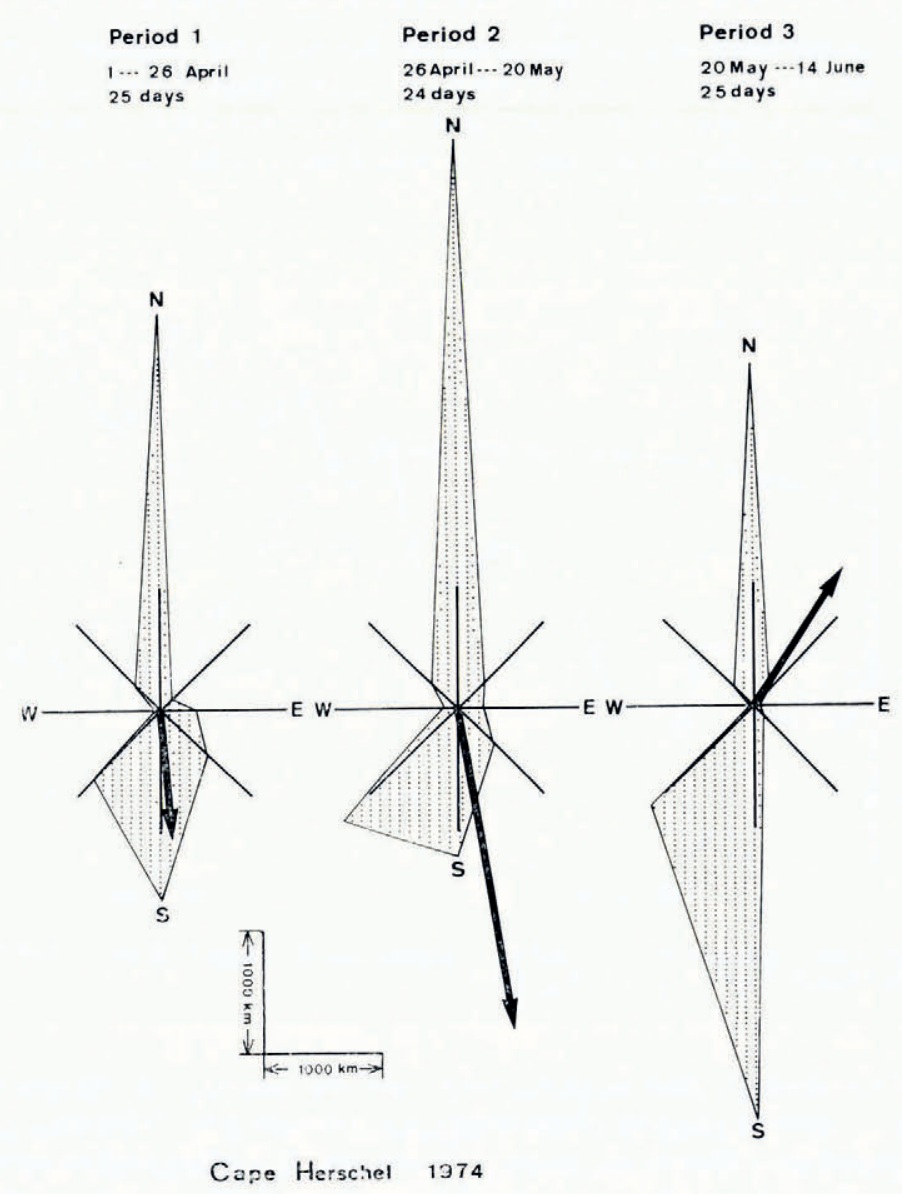

Fig. 5. Wind run (number of kilometres) from each direction together with resultant wind at Cape Herschel during displacement periods 1,2 and 3 in 1974 .

(b) The analysis of the stresses in the fast ice near the edge of the polynya (details of the stress measurements are given by Ito and Müller (in press)) shows that there are two distinctive zones; a narrow band of $\mathrm{r} .5$ to $2 \mathrm{~km}$ width along the edge of the fast ice, which is characterized by compression, and the rest which is predominantly a tension area. The stress in the two zones was found to be clearly different (Fig. 6). Because, as already mentioned, the position of the edge moves 2 to $3 \mathrm{~km}$ during a storm, a fixed point located initially in the tension zone would be found in the compression zone after one or more storms. The northwards-moving markers were located in the compression zone. The 1975 results support more strongly this second explanation. Points closer to the fast-ice boundary changed their direction of movement sooner than those located at greater distances. The upper left point (Fig. 3 B), the farthest from the boundary, stayed in the tension zone throughout the measuring period and did not change direction to the end. Further analysis of the stress data will be carried out to elucidate the more detailed mechanism relating stress and displacement on the meso-scale. 


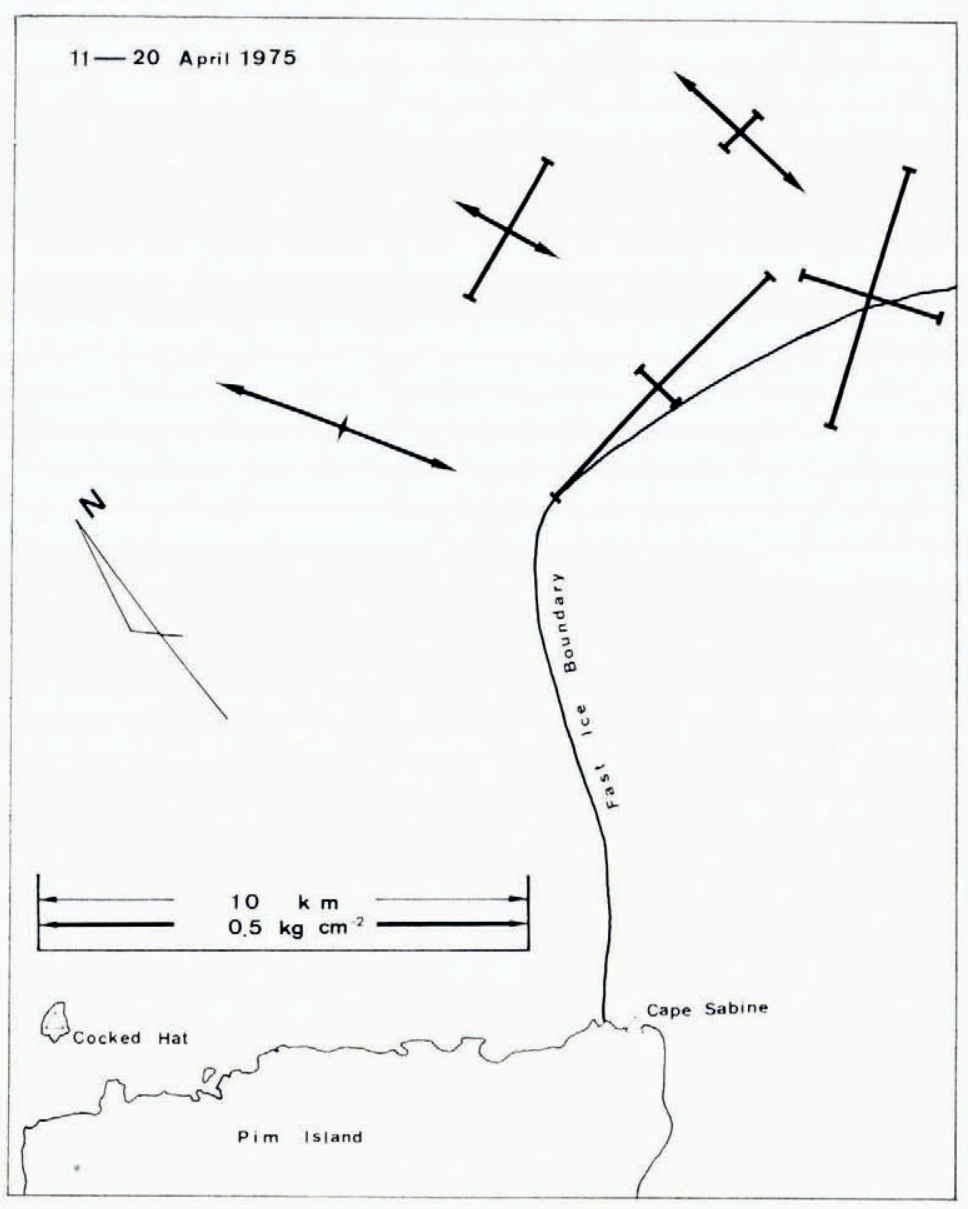

Fig. 6. Typical stress situations in the fast ice of Kane Basin.

Besides the north or south main direction of displacement in Kane Basin, in r974 an eastward, and in 1975 a westward, component was noticed. This difference was due to changes in the boundary conditions. There was old ice in both years in the north of Pim Island. In 1974 there was a huge ridged zone, with elevations of up to $5 \mathrm{~m}$, and $200 \mathrm{~m}$ to $2 \mathrm{~km}$ in width, between first year and old ice (Fig. 2, A). The ice movement was generally parallel to this boundary wall. Westward movement was prevented by the wall while the water edge towards the east was a free boundary, thus an eastward component developed, and this particularly strongly with the points lying close to the ridged zone. In I975 the border between first-year ice and old ice was not pronounced, and the coast line of Pim Island was, therefore, regarded as the boundary. The ice was compressed along the arch towards Pim Island, hence the westward component.

The large southward displacement in Jones Sound during the last period of 1976 needs additional explanation. Numerous cracks up to one metre wide with a south-west to north-east direction divided the fast ice into numerous strips which were, however, still part of the fast ice as they were connected together at the south-west end where the cracks disappeared. This fracture pattern was caused by the earlier break-off of fast ice along the steep Devon 
Island coast. The displacement during this period, therefore, contains both rigid-body movement as well as deformation. The two sources of displacement cannot clearly be separated. The cracks also appeared in the earlier part of the season but rapidly refroze unless the broken ice floe was immediately removed.

\section{Conclusions}

fast ice.

Classical surveying provides a workable method of measuring the horizontal movement of

The influx of sea ice through the fast-ice boundary into the polynya is very small. The rate of displacement increases with rising temperatures. The direction of displacement is determined by wind, current, and boundary conditions. Two zones with different stress situations producing different displacements were noticed. Large structural features, e.g. the ridged zone, may have to be considered as the boundary condition for the analysis instead of the coast line. Once cracks appear in the area, the displacement may contain both rigid-body movement and deformation.

\section{Acknowledgements}

Financial support for the project came from the Government of Canada (DSS Contract Number $\mathrm{OSX}_{4}$-0o98), the U.S. National Science Foundation (Contract Number GV40404 $\mathrm{AI}$ ) and the Schweizerische Nationalfonds zur Förderung der Wissenschaftlichen Forschung (Contract Number 2.383.70). Logistic support in the field was provided by the Polar Continental Shelf Project of the Department of Energy, Mines and Resources of Canada and by the Canadian Coast Guard, Ministry of Transport. The surveying instruments were loaned by the Institut für Geodäsie und Photogrammetrie of the ETH Zürich.

The authors wish to acknowledge the support from numerous agencies and individuals, especially Brian Hill's and Martin Braun's excellent field assistance and Roger Braithwaite's helpful suggestions with the analysis.

\section{REFERENCES}

Ito, H., and Müller, F. In press. Measurement of sea ice force by strain rosettes in the North Water area. [Paper presented at third International Conference on Port and Ocean Engineering under Arctic Conditions, Fairbanks, Alaska, 1975.]

Müller, F., and others. 1973. Das North Water Projekt, [by] F. Müller, A. Ohmura [and] R. Braithwaite. Geographica Helvetica, 28. Jahrg., Nr. 2, p. I I I-1 7 .

Müller, F., and others. 1975. Temperature measurement of ice and water surfaces in the North Water area using an airborne radiation thermometer, by F. Müller, H. Blatter and G. Kappenberger. Fournal of Glaciology, Vol. 15 , No. 73 , p. 24 I-50.

Zick, W., and Thiele, P. 1972. Geodätische Arbeiten im Rahmen des Canadian Arctic Channel Project, 1972. Polarforschung, Bd. 7, Jahrg. 42, Nr. 2, p. 82-89. 